\title{
PERBEDAAN KONSENTRASI PEREKAT ANTARA BRIKET BIOARANG TANDAN KOSONG SAWIT DENGAN BRIKET BIOARANG TEMPURUNG KELAPA TERHADAP WAKTU DIDIH AIR
}

\author{
Ilham Muzi, Surahma Asti Mulasari \\ Fakultas Kesehatan Masyarakat, Universitas Ahmad Dahlan, Yogyakarta, Indonesia \\ rahmasti_fkmuad@yahoo.com
}

\begin{abstract}
ABSTRAK
Latar Belakang: Tingkat pertumbuhan penduduk yang tinggi, menyebabkan meningkatnya konsumsi energi. Beberapa jenis sumber energi alternatif yang bisa dikembangkan yaitu energi biomassa. Potensi limbah biomassa terdiri dari sektor perkebunan yaitu tebu, kelapa sawit, kelapa, karet, kopi dan coklat yang dapat diolah menjadi briket bioarang. Dalam pembuatan briket bioarang memerlukan perekat sebagai penyatu bubuk arang dan mempengaruhi nilai kalor. Penelitian ini menggunakan briket bioarang tandan kosong sawit dan tempurung kelapa dengan konsentrasi perekat yang berbeda. Tujuan penelitian ini yaitu untuk mengetahui perbedaan pemberian konsentrasi perekat pada briket bioarang tandan kosong sawit dan tempurung kelapa terhadap waktu didih air.

Metode: Penelitian ini merupakan penelitian eksperimen dengan desain rancangan static group comparisons. Objek dalam penelitian ini adalah briket bioarang tandan kosong sawit dan tempurung kelapa dengan konsentrasi perekat $600 \mathrm{cc}$, $700 \mathrm{cc}$, $800 \mathrm{cc}$, dan $900 \mathrm{cc}$, untuk mengetahui waktu mendidihkan air sebanyak $1000 \mathrm{ml}$.

Hasil Penelitian: Uji Anova dengan nilai sig 0,289 > dari 0,05, yang berarti tidak ada perbedaan nyata waktu didih air antar konsentrasi yang berbeda pada briket bioarang tandan kosong sawit. Uji Anova dengan nilai sig 0,197, yang berarti tidak ada perbedaan nyata waktu didih air pada tempurung kelapa. Uji $t$-test didapatkan nilai sig 0,201 , sehingga tidak terdapat perbedaan yang signifikan untuk perbedaan waktu didih air briket bioarang tandan kosong sawit dengan tempurung kelapa.

Simpulan: Tidak ada perbedaan nyata waktu didih air pada konsentrasi yang berbeda pada briket bioarang tandan kosong sawit dan tempurung kelapa. Tidak terdapat perbedaan nyata waktu didih air antara briket bioarang tandan kosong sawit dengan tempurung kelapa.
\end{abstract}

Kata Kunci: Waktu didih air, briket bioarang, konsentrasi perekat, tandan kosong sawit, tempurung kelapa

\begin{abstract}
Background: Population growth in Indonesia 2000-2010 increased by 15\%. Along with the high population growth rate, the increase in energy consumption as well. Several types of alternative energy sources can be developed that biomass energy. Potential of biomass waste is composed of a sugar cane plantation, oil palm, coconut, rubber, coffee and chocolate can be processed into briquettes bioarang. In the manufacture of briquettes as a unifying glue bioarang require charcoal powder and affect calorific value. This study uses briquettes bioarang palm empty fruit bunches and palm shell with different concentrations of adhesive. The purpose of this research was to determine the differences of adhesive concentration on oil palm empty fruit bunches and coconut shell briquettes bioarang for a long time boiling water.

Methods: This study was experiment design with static group comparisons. Objects of this study was the briquettes bioarang palm empty fruit bunches and palm shell with adhesive concentration 600cc, 700cc, $800 \mathrm{cc}$, and 900cc, to determine as much time boiling $1000 \mathrm{ml}$ water.
\end{abstract}

Results: Anova test briquettes bioarang palm empty fruit bunches with sig 0,289, it had mean not real difference when boiling water. To bioarang briquette coconut shell with sig 0,197, it had 
mean not real difference when boiling water. T-test for the difference between the water boiling oil palm empty fruit bunches bioarang briquettes and coconut shell obtained sig 0,201 , so that there was no difference which significant.

Conclusion: There was no difference when boiling water with difference adhesive concentration on palm empty fruit bunches bioarang briquettes and coconut shell. There was no difference for a long time boiling water between palm empty fruit bunches and coconut shell briquettes bioarang.

Keywords: Time boiling water, briquette bioarang, concentration adhesive, stem of oil palm, coconut shell

\section{PENDAHULUAN}

Laju pertumbuhan penduduk di Indonesia setiap tahun mengalami peningkatan. Jumlah penduduk pada tahun 2000-2010 mengalami pertumbuhan sebesar $15 \%$. Seiring dengan tingkat pertumbuhan penduduk yang tinggi, tentunya akan semakin meningkatnya konsumsi energi. Di sisi lain, ketersedian akan sumber daya energi semakin lama akan habis. ${ }^{1}$ Energi sangat diperlukan oleh masyarakat untuk menunjang kebutuhan hidup. Seiring dengan berjalannya waktu dan bertambahnya penduduk, kebutuhan akan energi juga semakin meningkat, tetapi energi untuk kebutuhan sehari-hari semakin sulit didapat. ${ }^{2}$

Potensi limbah biomassa di Indonesia dibagi-bagi dalam beberapa sektor, yaitu sektor tanaman pangan yang terutama adalah padi, jagung, kacangkacangan, dan kedelai. Kemudian sektor perkebunan adalah tebu, kelapa sawit, kelapa, karet, kopi dan coklat. $^{3}$ Sumber energi alternatif dari biomassa perlu mendapatkan prioritas karena Indonesia sebagai negara agraris banyak menghasilakan limbah pertanian. Penggunaan biomassa sebagai energi alternatif memiliki keuntungan yaitu tersedia melimpah, murah, serta teknologinya mudah. ${ }^{4}$

Biomassa seringkali dianggap sebagai sampah dan sering dimusnahkan dengan di bakar. Salah satu pemanfaatan sampah biomassa adalah dengan dimanfaatkan menjadi briket bioarang. ${ }^{5}$ Pengelolaan sampah biomassa menjadi briket bioarang ini dapat memberikan beberapa keuntungan, diantaranya: nilai kalor yang dihasilkan oleh briket bioarang lebih tinggi dari pada biomassa. Nilai kalor briket bioarang pada pembuatan briket dari tandan kosong sawit dan cangkang sawit, briket bioarang yang dihasilkan memiliki nilai kalor 5303,07 $\mathrm{kal} / \mathrm{gr}^{6}$

Perekat diperlukan dalam pembuatan briket bioarang. Hal ini karena sifat alami bubuk arang yang cenderung saling memisah. Dengan bantuan bahan perekat atau lem, butir-butir arang dapat disatukan dan dibentuk sesuai kebutuhan. Pemilihan jenis perekat sangat berpengaruh terhadap kualitas bioarang. Hal ini disebabkan perekat akan mempengaruhi kalor pada saat pembakaran. ${ }^{7}$

Melihat berbagai cara yang telah dilakukan dalam pengelolaan briket bioarang dengan berbagai jenis biomassa dan campuran perekat yang menghasilkan karakteristik briket bioarang yang berbeda-beda. Maka pada penelitian ini peneliti akan melihat perbedaan briket bioarang dari tandan kosong sawit dan briket bioarang tempurung kelapa dengan konsentrasi perekat yang berbeda-beda yang digunakan untuk mendidihkan air.

\section{METODE PENELITIAN}

Penelitian ini merupakan penelitian eksperimental yaitu kegiatan percobaan (experiment), yang bertujuan untuk mengetahui suatu gejala atau pengaruh yang

KESMAS Vol. 8, No. 1, Maret 2014: 1 - 
timbul dari adanya perlakuan tertentu. Desain eksperimen yang digunakan adalah static group comparison. Pada rancangan ini, kelompok eksperimen menerima perlakuan (X) yang diikuti dengan pengukuran kedua atau observasi (02). Hasil dari pengukuran ini dikontrol atau dibandingkan dengan hasil penelitian pada kelompok kontrol. ${ }^{8}$ Penelitian ini dilakukan di Dusun Ngalarang, Desa Triharjo, Kecamatan Pandak, Kabupaten Bantul, Yogyakarta.

Bahan yang digunakan yaitu berasal dari perkebunan kelapa sawit dan pertanian kelapa di Desa Air Kelik, Belitung Timur, Belitung. Hal ini sekaligus untuk memberikan alternatif pengolahan limbah perkebunan kelapa sawit yang banyak tumbuh di Belitung. Hal ini diiringi dengan meningkatnya limbah pengolahan kelapa sawit yang dibuang begitu saja. Kondisi alam pantai di kepulauan Belitung banyak tumbuh pohon kelapa, sebanyak $1.875 \mathrm{Ha}$ lahan yang sudah digunakan sebagai perkebunan rakyat dan diperkirakan $800 \mathrm{Ha}$ yang mencakup dua kabupaten yaitu Belitung dan Belitung Timur yang banyak tumbuh subur pohon kelapa. Pertambahan luas areal perkebunan kelapa sawit di kepulauan Belitung dalam beberapa tahun ini terbilang pesat. Data terakhir berdasarkan luas hak guna usaha perusahaan dan perkebunan milik rakyat tercatat luas lahan sawit di kepulauan ini mencapai $44.487,58 \mathrm{Ha}^{5}$

Rancangan dari penelitian ini dapat digambarkan sebagai berikut:

\begin{tabular}{ccr}
\multicolumn{1}{c}{ Kelompok Eksperimen $\mathrm{a}$} & \multicolumn{1}{c}{ Perlakuan } & Postest \\
Kelompok Eksperimen $\mathrm{b}$ & $\longrightarrow$ & 02 \\
Xa 1 & 02 \\
Xa 2 & 02 \\
Xa 3 & 02 \\
Xb 1 & 02 \\
Xb 2 & 02 \\
Xb 3 & 02 \\
X0 &
\end{tabular}

Gambar 1. Rancangan penelitian

Xa1 : Perlakuan 1 (Briket bioarang tandan kosong sawit dengan konsentrasi perekat $700 \mathrm{cc}$ )

Xa2 : Perlakuan 2 (Briket bioarang tandan kosong sawit dengan konsentrasi perekat $800 \mathrm{cc}$ )

Xa3 : Perlakuan 3 (Briket bioarang tandan kosong sawit dengan konsentrasi perekat $900 \mathrm{cc}$ )

Xb1 : Perlakuan 1 (Briket bioarang tempurung kelapa dengan konsentrasi perekat 700cc)

Xb2 : Perlakuan 2 (Briket bioarang tempurung kelapa dengan konsentrasi $800 \mathrm{cc}$ )

Xb3 : Perlakuan 3 (Briket bioarang tempurung kelapa dengan konsentrasi 900cc)

X0 : Tidak diberi perlakuan (Briket bioarang dengan perekat standar, menggunakan perbandingan perekat $600 \mathrm{cc}$ )

02 : Pengukuran setelah perlakuan

\section{HASIL PENELITIAN DAN PEMBAHASAN}

Penelitian ini mengenai perbedaan konsentrasi perekat pada briket bioarang tandan kosong sawit dengan briket bioarang tempurung kelapa terhadap waktu didih air. Titik didih air adalah waktu yang digunakan briket untuk mencapai titik didih air $\left(100^{\circ} \mathrm{C}\right)$ pada $1000 \mathrm{ml}$. titk didih air ini merupakan salah satu karakteristik briket bioarang yang menunjukkan kualitas briket tersebut. ${ }^{5}$

Penelitian dimulai dari pembakaran pirolisis biomassa tandan kosong sawit dan tempurung kelapa hingga menjadi arang, arang yang dihasilkan tersebut ditumbuk dan diayak hingga menjadi bubuk arang, kemudian dicampur dengan berbagai konsentrasi perekat dan dicetak dengan alat pengepress briket bioarang 
hingga menyatu dan dikeringkan dengan menggunakan oven pada suhu $125^{\circ} \mathrm{C}$, selama 2 jam.

Perekat berfungsi untuk menyatukan butir-butir arang dan mudah dibentuk. Dalam penelitian ini menggunakan perekat tepung tapioka. Keunggulan perekat ini adalah mudah dibeli, murah dan mudah dibuat. Hal ini juga mempengaruhi kualitas ketika dinyalakan atau dibakar. Kelemahan dari perekat ini adalah hasil briket bioarang rentan ditumbuhi jamur ketika disimpan, sehingga terkesan bulukan dan berakibat pada permintaan konsumen. Untuk mengatasinya perlu ditambahi zat kimia antifungi pada saat pembuatan perekat. ${ }^{7}$ Perekat dari tepung tapioka ini banyak dimanfaatkan untuk pembuatan briket, salah satu contohnya adalah penelitian dengan biomassa kulit buah nipah. Tepung tapioka dipilih sebagai perekat dalam penelitian ini kemungkinan karena murah, mudah diperoleh, tersedian cukup banyak, mudah dalam pemanfaatanya, dan menghasilkan kekuatan rekat kering yang tinggi. ${ }^{4}$

\section{A. Hasil Penelitian}

1. Pengamatan Waktu Didih Air Dengan Konsentrasi Perekat Yang Berbeda Pada Briket Bioarang Tandan Kosong Sawit dan Pada Tempurung Kelapa a. Briket Bioarang Tandan Kosong Sawit

Hasil dari penelitian ini meliputi pengukuran waktu pendidihan air sebanyak $1000 \mathrm{ml}$ menggunakan briket bioarang tandan kosong sawit yang berbeda konsentrasi perekat. Pengujian dilakukan sebanyak lima kali pengulangan. Data waktu didih air disajikan dalam satuan detik. Hasil yang diperoleh dapat dilihat pada Tabel 1.

Tabel 1. Hasil pengamatan waktu didih air briket bioarang tandan kosong sawit dengan konsentrasi perekat

\begin{tabular}{ccccc}
\hline \multicolumn{5}{c}{ Briket Bioarang Tandan Kosong Sawit } \\
\cline { 2 - 5 } Pengulangan & \multicolumn{4}{c}{ Waktu didih air (detik) } \\
& $600 \mathrm{cc}$ & $\begin{array}{c}\text { Konsentrasi } \\
\text { perekat } \\
700 c c\end{array}$ & $\begin{array}{c}\text { Konsentrasi } \\
\text { perekat } \\
800 \mathrm{cc}\end{array}$ & $\begin{array}{c}\text { Konsentrasi } \\
\text { perekat } \\
900 \mathrm{cc}\end{array}$ \\
\hline 1 & 1638 & 1723 & 1793 & 1821 \\
2 & 1563 & 1456 & 1563 & 1624 \\
3 & 1575 & 1370 & 1378 & 1482 \\
4 & 1427 & 1315 & 1282 & 1576 \\
5 & 1545 & 1297 & 1496 & 1535 \\
$\Sigma$ & 7748 & 7161 & 7514 & 8108 \\
\hline Rerata & 1549,6 & 1432,2 & 1502,8 & 1621,6 \\
\hline
\end{tabular}

Waktu didih air dengan konsentrasi perekat $700 \mathrm{cc}$ dan $800 \mathrm{cc}$ yang menghasilkan waktu yang lebih singkat dalam mendidihkan air dibandingkan dengan konsentrasi kontrol $(600 \mathrm{cc})$, ini berarti konsentrasi perekat $700 \mathrm{cc}$ dan $800 \mathrm{cc}$ lebih cepat dalam mendidihkan air dibandingkan kontrol $(600 \mathrm{cc})$. Untuk menentukan waktu didih air yang lebih cepat maka konsentrasi $700 \mathrm{cc}$ dibandingkan dengan $800 \mathrm{cc}$, dari pembandingan tersebut menunjukan konsentrasi $700 \mathrm{cc}$ yang menghasilkan waktu didih air yang lebih cepat. Sedangkan konsentrasi perekat $900 \mathrm{cc}$ membutuhkan waktu didih air sedikit lebih lama 
dibandingkan dengan kontrol $(600 \mathrm{cc})$. Jadi ada perbedaan waktu didih air dengan konsentrasi perekat pada briket bioarang tandan kosong sawit.

Tabel 2. Hasil uji Anova perbedaan waktu didih air dengan konsentrasi perekat yang berbeda pada briket bioarang tandan kosong sawit

\begin{tabular}{lccccc}
\hline & $\begin{array}{c}\text { Sum of } \\
\text { Squares }\end{array}$ & Df & $\begin{array}{c}\text { Mean } \\
\text { Sguares }\end{array}$ & F & Sig. \\
\hline Between Groups & 95158.950 & 3 & 31719.650 & 1.367 & 0.289 \\
Within Groups & 371234.000 & 16 & 23202.125 & & \\
Total & 466392.950 & 19 & & & \\
\hline
\end{tabular}

Hasil analisis statistik menggunakan Anova dengan tingkat kepercayaan $95 \%$ didapatkan nilai sig sebesar 0,289. Jadi nilai sig $>0.05$ maka $\mathrm{HO}$ diterima. Artinya tidak ada perbedaan signifikan waktu didih air dengan menggunakan konsentrasi perekat yang berbeda. Uji Turkey untuk mengetahui konsentrasi perekat mana yang berbeda nyata dalam mendidihkan air tidak dilakukan karena pada uji Anova menunjukkan tidak ada perbedaan waktu didih air dengan konsentrasi perekat yang berbeda.

b. Briket Tempurung Kelapa

Hasil penelitian meliputi pengukuran waktu didih air menggunakan briket bioarang tempurung kelapa yang berbeda konsentrasi perekat. Pengujian dilakukan dengan lima kali pengulangan. Data waktu didh air disajikan dalam satuan detik. Hasil yang diperoleh dapat dilihat pada Tabel 3 .

Tabel 3. Hasil pengamatan waktu didih air briket bioarang tempurung kelapa dengan konsentrasi perekat yang berbeda

\begin{tabular}{ccccc}
\hline & \multicolumn{4}{c}{ Briket Bioarang Tempurung Kelapa } \\
\hline \multirow{3}{*}{ Pengulangan } & \multicolumn{4}{c}{ Waktu didih air (detik) } \\
\cline { 2 - 5 } & $\begin{array}{c}\text { Kontrol } \\
600 \mathrm{cc}\end{array}$ & $\begin{array}{c}\text { Konsentrasi } \\
\text { perekat } \\
700 \mathrm{cc}\end{array}$ & $\begin{array}{c}\text { Konsentrasi } \\
\text { perekat } \\
800 \mathrm{cc}\end{array}$ & $\begin{array}{c}\text { Konsentrasi } \\
\text { perekat } \\
900 \mathrm{cc}\end{array}$ \\
\hline 1 & 1463 & 1347 & 1561 & 1583 \\
2 & 1388 & 1382 & 1457 & 1507 \\
3 & 1425 & 1425 & 1326 & 1429 \\
4 & 1491 & 1471 & 1410 & 1565 \\
5 & 1508 & 1422 & 1596 & 1479 \\
$\Sigma$ & 7275 & 7047 & 7350 & 7563 \\
\hline Rerata & 1455 & 1409,4 & 1470 & 1512,6 \\
\hline
\end{tabular}

Waktu didih air dengan konsentrasi perekat $700 \mathrm{cc}$ yang membutuhkan waktu 1409,4 detik dibandingkan dengan konsentrasi kontrol $(600 \mathrm{cc})$ yang membutuhkan waktu 1455 detik, ini berarti konsentrasi perekat $700 \mathrm{cc}$ lebih cepat dalam mendidihkan air dibandingkan dengan kontrol $(600 \mathrm{cc})$. Untuk konsentrasi perekat $800 \mathrm{cc}$ dan $900 \mathrm{cc}$ membutuhkan waktu didih air sedikit lebih lama dibandingkan dengan kontrol (600cc). Jadi terdapat perbedaan waktu didih air dengn konsentrasi perekat pada briket bioarang tempurung kelapa. 
Tabel 4. Hasil uji Anova perbedaan waktu didih air dengan konsentrasi perekat yang berbeda pada briket bioarang tempurung kelapa

\begin{tabular}{lccccc}
\hline & $\begin{array}{c}\text { Sum of } \\
\text { Squares }\end{array}$ & Df & $\begin{array}{c}\text { Mean } \\
\text { Sguares }\end{array}$ & F & Sig. \\
\hline Between Groups & 27199.350 & 3 & 9066.450 & 1.750 & 0.197 \\
Within Groups & 82912.400 & 16 & 5182.025 & & \\
Total & 110111.750 & 19 & & & \\
\hline
\end{tabular}

Hasil analisis statistik menggunakan Anova dengan tingkat kepercayaan 95\% didapatkan nilai sig sebesar 0,197. Jadi nilai sig $>0.05$ maka $\mathrm{HO}$ diterima. Artinya tidak ada perbedaan signifikan waktu didih air dengan menggunakan konsentrasi perekat yang berbeda. Uji Turkey untuk mengetahui konsentrasi perekat mana yang berbeda nyata dalam mendidihkan air tidak dilakukan karena pada uji Anova menunjukkan tidak ada perbedaan waktu didih air dengan konsentrasi perekat yang berbeda.

2. Pengamatan rerata waktu didih air antara briket bioarang tandan kosong sawit dengan tempurung kelapa

Rerata waktu didih air yang dihasilkan dari briket bioarang tandan kosong sawit dibandingkan dengan briket bioarang tempurung kelapa. Hal ini dilakukan untuk mengetahui perbedaan rerata waktu didih air diantara dua jenis briket tersebut.

Tabel 5. Hasil pengamatan rerata waktu didih air antara briket bioarang tandan kosong sawit dengan tempurung kelapa.

\begin{tabular}{ccc}
\hline Konsentrasi & \multicolumn{2}{c}{ Waktu didih air (detik) } \\
\cline { 2 - 3 } & Rerata Tandan Kosong Sawit & Rerata Tempurung Kelapa \\
\hline $600 \mathrm{cc}$ & 1549,6 & 1455 \\
$700 \mathrm{cc}$ & 1432,2 & 1409,4 \\
$800 \mathrm{cc}$ & 1502,8 & 1470 \\
$900 \mathrm{cc}$ & 1621,2 & 1512,6 \\
$\Sigma$ & 6106,2 & 5847 \\
Rerata & 1526,55 & 1461,75 \\
\hline
\end{tabular}

Dari tabel di atas dapat dilihat bahwa lama waktu untuk mendidihkan air $1000 \mathrm{ml}$ menggunakan briket bioarang tandan kosong sawit dengan rerata 1526,55 detik, sedangkan briket bioarang tempurung kelapa dengan rerata 1461,75 detik. Untuk mengetahui kemaknaan secara statistik maka dilakukan uji $t$-test. 
Tabel 6. Hasil uji t-test perbedaan rerata waktu didih air antara briket bioarang tandan kosong sawit dan briket bioarang tempurung kelapa

\begin{tabular}{ccccccc}
\hline & $\begin{array}{c}\text { Levene's Test } \\
\text { for Equality of } \\
\text { Variances }\end{array}$ & & t-test for Equality of Means \\
& F & Sig. & T & Df & $\begin{array}{c}\text { Sig. (2- } \\
\text { tailed) }\end{array}$ & $\begin{array}{c}\text { Mean } \\
\text { Difference }\end{array}$ \\
\hline $\begin{array}{c}\text { Equal } \\
\text { variances assumed } \\
\begin{array}{c}\text { Equal } \\
\text { variances not assumed }\end{array}\end{array}$ & 1,485 & 0,269 & 1.435 & 6 & .201 & 64.8000 \\
\hline
\end{tabular}

Berdasarkan hasil uji $t$-test, nilai signifikansi yang di dapat sebesar 0,201 . Jadi nilai $\mathrm{sig}>0.05$ maka HO diterima. Artinya tidak ada perbedaan secara signifikan antara briket bioarang tandan kosong sawit dengan briket bioarang tempurung kelapa terhadap waktu didih air.

\section{B. Pembahasan}

a. Perbedaan waktu didih air dengan konsentrasi perekat yang berbeda pada briket bioarang tandan kosong sawit dan pada briket bioarang tempurung kelapa

Perekat dalam pembuatan briket bioarang berpengaruh pada kualitas briket tersebut. Apabila jumlah perekat tidak sesuai dengan komposisi bioamassa maka ketika briket tersebut dicetak hasil cetakan akan terlalu kering dan mudah hancur. Pencampuran perekat yang tidak merata menyebabkan cetakan patah-patah ketika keluar dari cetakan briket.

Hambatan dan tantangan membuat briket ketika di lapangan biasanya adalah cetakan terlalu kering, cetakan sulit keluar dari cetakan, cetakan bapat, dan cetakan tidak simetris. Penyebab cetakan terlalu kering adalah kekurangan perekat. Penyebab cetakan patah-patah adalah perekat tidak tercampur homogen. ${ }^{7}$ Proses pembuatan briket bioarang dibutuhkan perekat untuk menyatukan partikel-partikel di dalam bahan baku. Fungsi perekat adalah sebagai bahan untuk menstabilkan panas agar tidak pecah. ${ }^{2}$

Bedasarkan hasil dari analisis deskriptif dari penggunaan konsentrasi perekat pada briket bioarang tandan kosong sawit dan tempurung kelapa bahwa konsentrasi perekat 700cc merupakan konsentrasi perekat yang cepat dalam mendidihkan air dan konsentrasi perekat 900cc merupakan konsentrasi perekat yang lama dalam mendidihkan air. Hal tersebut membuktikan bahwa semakin banyak dalam menggunakan konsentrasi perekat yang digunakan, maka akan memperburuk nilai panas atau kalor yang dihasilkan. Perekat yang terlalu berlebih menghambat pori-pori briket sehingga oksigen yang dibutuhkan untuk pembakaran tidak ada. Hal tersebut akan menghambat proses pembakaran karena tidak adanya oksigen dan kemungkinan berdampak dengan mengurangi panas yang dihasilkan saat pembakaran briket biorang saat proses pendidihan air.

Pemilihan perekat dan konsentrasi yang tepat akan membantu menaikkan kalor. Sehingga dalam penelitian ini konsentrasi perekat 700cc adalah konsentrasi yang baik dibanding dengan yang lain. Semakin banyak 
penambahan perekat akan menurunkan nilai kalor. Hal ini kemungkinan karena sifat perekat yang digunakan yaitu tepung tapioka yang memudah membantuk gel.

Perlakuan variasi penambahan tepung sagu sebagai perekat sangat berpengaruh terhadap waktu untuk mencapai titik didih air briket bioarang. ${ }^{5}$ Penambahan tepung tapioka dan kapur yang semakin banyak dalam adonan briket menyebabkan penurunan nilai kalor. Hal ini disebabkan karena sifat tepung tapioka yang dapat menjadi gel. ${ }^{9}$ pada Penggunaan perekat semakin sedikit dinilai semakin baik. Semakin sedikit campuran perekat (tepung kanji) maka semakin tinggi nilai kalornya. ${ }^{10}$

Hasil penelitian ini tidak sejalan dengan penelitian yang menyatakan semangkin besar persen konsentrasi perekat yang digunakan dalam campuran maka didapatkan nilai kalor yang tinggi dan ketahanan briket yang terbaik. ${ }^{11}$

Bedasarkan hasil analisis secara statistik dengan uji Anova bahwa tidak ada perbedaan waktu didih air yang signifikan dengan pemberian konsentrasi perekat yang berbeda pada briket bioarang tandan kosong sawit dan briket bioarang tempurung kelapa, sehingga pengujian untuk melihat konsentrasi perekat yang paling berbeda nyata terhadap waktu waktu didih air pada tabel comparisons tidak dilakukan. Hasilnya adalah tidak terdapat perbedaan nyata pada konsentrasi perekat kontrol (600cc) dengan $900 \mathrm{cc}$, 700cc dengan $800 \mathrm{cc}$ dan $900 \mathrm{cc}$, serta $800 \mathrm{cc}$ dengan $900 \mathrm{cc}$ terhadap waktu didih air briket bioarang tandan kosong sawit dan briket bioarang tempurung kelapa.

Hal ini kemungkinan disebabkan oleh bubuk arang yang dihasilkan dari briket bioarang tandan kosong sawit dan tempurung kelapa tersebut yang sangat kering serta halus pada proses pengeringan dan penumbukan. Butir-butir yang kecil tersebut mengadung kadar air rendah dan relatif sama. Kadar air mempengaruhi nilai kalor. Karena banyaknya bubuk arang yang dimasukkan dalam adonan briket sama dan yang divariasikan adalah perekat, maka kadar air dalam briket bioarang pada saat pembakaran relatif sama. Hal ini menyebabkan jarak atau selisih waktu didih air dari keempat konsentrasi perekat tersebut pun tidak berbeda jauh. Pada saat dicetak, yang mempengaruhi kadar air dalam briket lebih dominan adalah dari biomassa, perekat tidak mengikat air dalam briket.

b. Perbandingan waktu didih air antara briket bioarang tandan kosong sawit dengan briket bioarang tempurung kelapa

Hal yang mempengaruhi rerata waktu didih air pada briket bioarang tandan kosong sawit dan briket bioarang tempurung kelapa dikarenakan pada proses pengeringannya menggunakan oven pada suhu $125^{\circ} \mathrm{C}$, selama dua jam hingga menjadi benar-benar kering. Selain itu kandungan air dalam tempurung kelapa memang sedikit sehingga proses pembakaran briket menjadi lebih cepat, sehingga menyebabkan proses pendidihan air menjadi lebih singkat dibandingkan briket bioarang tandan kosong sawit.

$\mathrm{Hal}$ ini sesuai dengan hasil penelitian yang menyebutkan bahwa kadar air dari tempurung kelapa adalah 6,00 persen per kilogram. ${ }^{3}$ Kadar air briket berpengaruh terhadap nilai kalor, semakin kecil nilai kadar air maka semakin baik nilai kalornya. ${ }^{2}$

Secara deskriptif terdapat perbedaan pada rerata waktu didih air briket bioarang tandan kosong sawit dan briket bioarang tempurung kelapa,

KESMAS Vol. 8, No. 1, Maret 2014 : 1 - 
akan tetapi secara statistik didapatkan nilai sig 0,201 yang berarti nilai sig > dari 0,05 sehingga Ho diterima. Artinya tidak ada perbedaan waktu didih air antara briket bioarang tandan kosong sawit dan briket bioarang tempurung kelapa.

Hal ini disebabkan kandungan selulosa dan holoselulosa yang relatif sama pada tandan kosong sawit dan tempurung kelapa sehingga kandungan karbon yang dihasilkan relatif sama. Kandungan karbon dalam briket bioarang berguna meningkatkan nilai panas briket bioarang.

Komposisi kimia tandan kosong sawit yang berupa selulosa sebesar 45,80 persen dan kandungan holoselulosa sebesar 71,88 persen. Sehingga berkadar karbon tinggi dan mempunyai berat jenis yang lebih tinggi, sehingga karakteristik ini memungkinkan bahan tersebut baik untuk dijadikan arang serta mempunyai nilai kalor yang juga tinggi. ${ }^{13}$ Tempurung kelapa merupakan lapisan keras yang terdiri dari lignin, selulosa, metoksil dan struktur yang keras disebabkan oleh silikat $(\mathrm{SiO})$ yang cukup tinggi kadarnya pada tempurung, sehingga tempurung kelapa dapat diolah menjadi arang. ${ }^{14}$

Kandungan karbon dalam briket bioarang menghasilkan nilai panas pada briket, apabila kandungan karbon meningkat maka nilai panas yang dihasilkan juga tinggi. Briket bioarang yang berasal dari tandan kosong sawit dan tempurung kelapa ini memiliki prospek yang dapat diandalkan karena pemanfaatan limbah tandan kosong sawit dan tempurung kelapa menjadi briket sangat menguntungkan bagi petani dan konsumen. Biayanya lebih murah dan terjangkau dibanding menggunakan arang kayu, minyak tanah dan kompor gas. ${ }^{15}$

\section{SIMPULAN DAN SARAN}

1. Tidak ada perbedaan nyata waktu didih air dengan menggunakan konsentrasi perekat yang berbeda pada briket bioarang tandan kosong sawit dan pada briket bioarang tempurung kelapa.

2. Tidak ada perbedaan nyata waktu didih air antara briket bioarang tandan kosong sawit dengan briket bioarang tempurung kelapa.

\section{DAFTAR PUSTAKA}

1. BPS, Data Jumlah Penduduk Di Indonesia, http://Bps.go.id, diakses tanggal 21 Desember 2012. Yogyakarta. 2011.

2. Alphan, L., Hendrarini, Kartono, Pengaruh Bentuk Briket Blotong Terhadap Lama Waktu Mendidihkan Air Dan Lama Membara. Jurnal Kesehatan Lingkungan, 3(3): 101-105. 2011.

3. Wilasita, R., Purwaningsih, Pemanfaatan Limbah Tongkol Jagung Dan Tempurung Kelapa Menjadi Briket Sebagai Sumber Energi Alternatif Dengan Proses Karbonisasi Dan Non Karbonisasi. Jurnal Penelitian Sains, ITS, Surabaya: http://digilib.its.ac.id/pemanfaatan-limbah-tongkol-jagung-dan-tempurung-kelapa-menjadibriket-sebagai-sumber-energi-alternatif-dengan-proses-karbonisasi-dan-non-karbonisasi16948.html, Diakses tangggal 5 Desember 2013 di Yogyakarta. 2011.

4. Mulyadi, A.F. Dewi, I.A., Deoranto, P., Pemanfaatan Kulit Buah Nipah Untuk Pembuatan Briket Bioarang Sebagai Sumber Energi Alternatif. Jurnal Teknologi Pertanian 14(1): 65-72. 2013.

5. Saleh, M., R. E., Karakteristik Briket Bioarang Limbah Pisang Dengan Perekat Tepung Sagu. Prosiding Seminar Rekayasa Kimia dan Proses, ISSN 1411-4216 : 1-5. 2010. 
6. BPS, Statistik Daerah Kabupaten Belitung Timur, http:// Bps.go.id, diakses tanggal 28 Januari 2013, Yogyakarta. 2010.

7. Kurniawan, O., Marsono. Superkarbon ; Bahan Bakar Alternatif pengganti Minyak Tanah dan Gas Briket Arang dari Sampah dan Limbah Pertanian. Penerbit Penebar Swadaya. Depok. 2008.

8. Notoatmodjo, S., Metodologi Penelitian Kesehatan, Edisi Revisi, Rineka Cipta, Jakarta. 2005

9. Mulyadi, A.F. Dewi, I.A., Deoranto, P., Pemanfaatan Kulit Buah Nipah Untuk Pembuatan Briket Bioarang Sebagai Sumber Energi Alternatif. Jurnal Teknologi Pertanian. 14 (1) : 6572. 2013.

10. Susana, I.G.B. Peningkatan Nilai Kalor Biomassa Kotoran Kuda Dengan Metode Denfisikasi dan Thermolisis. Jurnal Teknik Mesin 11(2) : 100-107. 2009.

11. Hanandito, S., Willy, Pembuatan Briket Arang Tempurung Kelapa Dari Sisa Bahan Bakar Pengasapan Ikan Kelurahan Bandarharjo Semarang. Teknik Kimia. Fakultas Teknik. Universitas Diponegoro, Semarang. Diakses pada eprints.undip.ac.id/36696/1/3.Artikel_IImiah.pdf, tanggal 5 Desember 2013, di Yogyakarta : 1-9. 2011.

12. Nurainy, R., Sumiyati, S., Sutrisno, E. Pemanfaatan Ampas Bioetanol Dari Kulit Pisang (Musa sapientum) Sebagai Briket. Jurnal Teknik Lingkungan 2(2). Universitas Diponegoro, Semarang : 1-8. 2013.

13. Ndraha, N., Uji Komposisi Bahan Pembuat Briket Bioarang Tempurung Kelapa dan Serbuk Kayu terhadap Mutu yang Dihasilkan, Skripsi, Universitas Sumatra Utara, Medan. 2009.

14. Novika, Aneka Kreasi Dari Limbah Kelapa, Kriya Pustaka, Jakarta. 2007.

15. Mariyani dan Rumijati, Pengaruh Penambahan Bulu Ayam Terhadap Kandungan Karbon Briket Bioarang Sampah Pekarangan. Jurnal Penelitian Sains dan Teknologi, 5 (2) : 83-85. 2004. 